Matgorzata Pietrasiak

Uniwersytet Łódzki

\title{
Partnerstwo strategiczne Metody i środki polityki zagranicznej Chińskiej Republiki Ludowej wobec Rosji
}

\section{Uwarunkowania rosyjskiej polityki na tle sytuacji w regionie Azji Pólnocno-Wschodniej}

Rozpad ZSRR pod koniec 1991 r. był wielkim wstrząsem dla całego kontynentu euroazjatyckiego. Jego oddziaływanie miało również szerszy, międzykontynentalny wymiar. Zmieniła się struktura systemu międzynarodowego, a na gruzach ZSRR powstało 15 niepodległych państw. Od tej pory Federacja Rosyjska jest samodzielnym podmiotem, który jako sukcesor ZSRR odziedziczył stolicę, hymn i wolę odbudowy pozycji międzynarodowej zajmowanej w okresie zimnowojennym. Rosja pozostaje największym państwem na świecie. Łączna długość jej granic wynosi 60 tys. $900 \mathrm{~km}$, z czego na granicę lądową przypada ponad 20 tys km. Najdłuższe granice Rosja ma z Chinami - od południa $40 \mathrm{~km}$ i od południowego wschodu $3605 \mathrm{~km}^{1}$.

Polityczny chaos, jaki miał miejsce po upadku ZSRR, w sposób bardzo widoczny odbił się na rosyjskiej gospodarce. W latach 1991-1995 produkt krajowy brutto Rosji zmniejszył się o 35\% w stosunku do PKB ZSRR z lata 1985-1986. Dodatkowo kryzys finansowy końca lat 90 . nie sprzyjał wyjściu tego kraju z zapaści gospodarczej. Dopiero lata 2000. przyniosły zdecydowaną poprawę. Według informacji zamieszczonych na stronach polskiego Ministerstwa Gospodarki obecnie Rosja należy do krajów odnotowujących wysokie tempo wzrostu gospodarczego. Kryzys 2009 r. spowodował jego spowolnienie, ale „wzrost od drugiego półrocza 2010 r. cen surowców energetycznych oraz działania antykryzysowe władz spowodowały, że sytuacja gospodarcza w 2010 r. zaczęła ulegać poprawie. Rosnąca cena ropy naftowej pozytywnie wpłynęła na poziom PKB, wysokość

${ }^{1}$ E. Cziomer, L.W. Zyblikiewicz, Zarys wspótczesnych stosunków międzynarodowych, Wydawnictwo PWN, Warszawa 2006, s. 386. 
dochodów budżetowych i stan rezerw walutowych. W 2010 r. PKB Rosji wzrósł o 4\%, dochody budżetowe były wyższe, niż zakładano, o 5,4\%, deficyt budżetu wyniósł 3,9\% PKB"2. Według danych Banku Światowego PKB Rosji w roku 2010 osiągnęło 1479819314058 USD $^{3}$.

W połowie lat 90., kiedy Rosja walczyła o ustabilizowanie swojej sytuacji wewnętrznej, w jej najbliższym sąsiedztwie wyrosła nowa potęga gospodarcza - Chińska Republika Ludowa. Silną pozycję, pomimo licznych kłopotów, utrzymywała Japonia, a integrująca się Europa wchłonęła szereg państw, które do niedawna pozostawały częścią obozu socjalistycznego. Dla Rosji oznaczało to konieczność poszukiwania miejsca dla siebie w powstającym nowym systemie międzynarodowym. Najbardziej naturalną ideą było wykorzystanie położenia geograficznego jako pomostu między Europą i Azją (a nawet Ameryką). Azję Wschodnią zaczęto postrzegać jako region sukcesów gospodarczych takich potęg, jak: Japonia, Korea Południowa czy wreszcie Chiny. U źródeł nowej koncepcji polityki wobec regionu leżała możliwość odegrania bardziej znaczącej roli w tworzącym się, w miejsce dwubiegunowego, multipolarnym modelu świata. W Azji bowiem znajdują się potęgi gospodarcze walczące również o adekwatne miejsce w polityce międzynarodowej. Tak więc, aby wzmocnić swój autorytet na arenie międzynarodowej, Rosja zaczęła szukać sojuszników właśnie w Azji.

Z punktu widzenia Rosji przyjazne stosunki z Chinami służyły, ,zabezpieczeniu tyłów" w czasie redefinicji stosunków z państwami zachodnimi. Moskwa nadal wiązała swoje najważniejsze interesy z Europą i Stanami Zjednoczonymi. Rosyjski rząd zainicjował radykalne reformy ekonomiczne, czego rezultatem stał się w pierwszym okresie wielki chaos gospodarczy i polityczny oraz hiperinflacja. Ten kontrast: spadek pozycji Rosji przy jednoczesnym bogaceniu się do niedawna słabszych sąsiadów azjatyckich spowodował, że na oczach jednego pokolenia Rosja z dominującej przekształcała się w biedniejszą, słabszą ekonomicznie stronę w odniesieniu do Chin. W Rosji cały czas istnieją obawy, że mimo ,partnerstwa strategicznego" wątpliwe, by Chiny zechciały pomóc jej stać się pełnoprawnym uczestnikiem procesu integracji w regionie Azji i Pacyfiku.

\section{Cele polityki chińskiej wobec Rosji}

Historycznie rzecz ujmując, polityka Chin wobec Rosji związana była z dążeniem do zbudowania równoprawnych i wzajemnie korzystnych stosunków. Od początku sąsiedztwa stroną dominującą w relacjach wzajemnych było Imperium

2 http://www.mg.gov.pl/Wspolpraca+z+zagranica/Wspolpraca+gospodarcza+Polski+z+krajami+wschodnimi+i+pozaeuropejskimi/Rosja.htm [dostęp 15.05.2012].

3 http://data.worldbank.org/country/russian-federation [dostęp 15.05.2012]. 
Rosyjskie, a potem Związek Radziecki. Zawarte w tym czasie traktaty między państwami były nierównoprawne, ale w ciągu owych 300 lat relacje były raczej pokojowe. Rosja i Chiny nigdy nie pozostawały formalnie w stanie wojny. Najtrudniejszy okres przypadł na koniec lat 90. XIX w., kiedy stosunki rosyjskochińskie wyraźnie wstąpiły w nową fazę z powodu imperializmu rosyjskiego i przechylały się na rzecz interesów ekonomicznych i kolonialnych Rosji. Wyraźnie przypominały te, które Chiny miały z państwami zachodnimi, choć w interesie Rosji leżało istnienie sąsiada jako państwa przyjaznego i zintegrowanego.

Krótki okres bliskich stosunków, jakie istniały w relacjach wzajemnych po proklamowaniu Chińskiej Republiki Ludowej, nie był oparty na solidnych podstawach i nie oznaczał rozwiązania sporów politycznych i terytorialnych, nic więc dziwnego, że lata 60. XX w. charakteryzowały się wrogością, która doprowadziła nawet do otwartego konfliktu zbrojnego w 1969 r. To krótkie historyczne wprowadzenie do analizy celów polityki Chin wobec Rosji jest konieczne, aby nakreślić źródła nieufności we wzajemnych relacjach. W analizach naukowych, ale również w wypowiedziach oficjalnych i publicystyce, pojawia się wątek związany z procesem przezwyciężania nieufności w stosunkach dwustronnych. O ile po stronie chińskiej odwołuje się najczęściej do pierwiastka historycznego, to po stronie rosyjskiej nieufność wynika z aktualnej niekwestionowanej pozycji lidera, co ma wpływ nie tylko na pozycję międzynarodową Rosji, ale i niektóre aspekty jej polityki wewnętrznej. Jak zauważa rosyjski ekspert ds. spraw chińskich A. Lukin, dla Chin ważniejsze jest, aby Rosja pozostała dostawcą surowców strategicznych niż pomaganie jej w zdobywaniu nowych rynków ${ }^{4}$.

Pamiętać należy przy tym, że nie tylko Stany Zjednoczone, ale również Chiny przez wiele lat dążyły do osłabienia pozycji militarnej i gospodarczej Rosji w regionie i fakt, że straciła ona status supermocarstwa, był dla Chin pozytywnym elementem budowy z nią nowych relacji ${ }^{5}$.

Jak już było powiedziane, pomimo obarczenia wzajemnych relacji pewną nieufnością, nierozwiązanymi zaszłościami historycznymi w okresie pozimnowojennym, oba państwa stają się naturalnymi sojusznikami na arenie międzynarodowej. Proces ten rozpoczął się w latach 80 . XX w., a obecnie w wielu punktach cele polityki chińskiej wobec Rosji są zbieżne z rosyjskimi i, jak zapisano na stronie internetowej Ministerstwa Spraw Zagranicznych ChRL, sprowadzają się do: osiągnięcia wzajemnego zaufania, wymiany międzyludzkiej i koordynacji strategicznych celów na „niespotykanym do tej pory poziomie”. Obecnie opierają się w szczególności na następujących wspólnych założeniach:

${ }^{4}$ A. Lukin, Russia and the Emerging Institutional Order in the Asia-Pacific, http://www. ascc2011.org/papers/Lukin_Paper.pdf [dostęp 2.10.2012].

5 A. Woskriesienskij, Rossija i Kitaj, faktory wzaimodiejstwija, [w:] Kitaj w mirowoj politikie, ROSSPEN, Moskwa 2001, s. 272.

${ }_{6}$ http://www.fmprc.gov.cn/eng/wjb/zzjg/dozys/gjlb/3220/ [dostęp 15.11.2012]. 
1. Krytycznej postawie wobec niektórych aspektów polityki państw zachodnich. Była ona najbardziej słyszalna w czasie podejmowania przez Amerykanów inicjatywy interwencji w Iraku i Jugosławii. Szczególnie wojna w Kosowie, podjęta wbrew woli Rosjan i Chińczyków, uświadomiła obu rządom konieczność bliskiej współpracy na arenie międzynarodowej w celu zrównoważenia hegemonii jednego państwa. Jednostronne ogłoszenie niepodległości przez Kosowo w lutym 2008 r. zostało ostro skrytykowane przez Rosję i Chiny. Interwencje NATO w Afryce Północnej, w tym w Libii, są również krytycznie przyjmowane przez oba państwa.

2. Ze wspomnianymi postawami związane jest wyznawanie i podkreślanie wspólnych wartości w polityce międzynarodowej, takich jak: suwerenność państw i zasada nieinterwencji w sprawy wewnętrzne państw?

3. W polityce chińskiej i rosyjskiej element równowagi sił, kierunek budowy świata wielobiegunowego są podstawowymi zasadami tworzenia relacji międzynarodowych - Chiny nie chcą monopolu żadnej ze stron trzecich ${ }^{8}$. Współpraca z Rosją może się przydać dla utrzymania równowagi sił w północnej Azji i dla zabezpieczenia przed jednostronnym umocnieniem wpływów USA i Japonii.

4. Wspólne zainteresowanie stabilnością w regionie. Chiny liczą na wsparcie w razie rozruchów w Tybecie czy muzułmańskim Xinjiangu. Potrzebują pomocy Rosji w walce z ekstremizmem muzułmańskim w Azji Środkowej. Wolą dzielić się wpływami w tej ważnej strategicznie części Azji (położenie oraz surowce) z Rosjanami niż Amerykanami, którzy starają się włączyć Kazachstan czy Turkmenistan w orbitę własnych wpływów. Wspólne zainteresowanie stabilnością w regionie to również współpraca $\mathrm{w}$ ramach rozmów sześciostronnych w sprawie Korei i minimalizowanie groźby destabilizowania sytuacji wynikającej z czynnika koreańskiego.

5. Obopólna wymiana doświadczeń w dziedzinie wojskowości oraz zainteresowanie Rosji i Chin tym, aby państwa trzecie nie wykorzystały obu państw dla własnych interesów.

6. Z punktu widzenia Pekinu partnerstwo z Rosją może się też okazać ważnym atutem w grze o Tajwan, jaką prowadzi on z USA. Po powrocie Makau do Chin (20 grudnia 1999 r.) Tajwan pozostał jedyną enklawą chińską poza centralnymi Chinami. Jedną z kart przetargowych ChRL jest arsenał głowic atomowych zdolnych dosięgnąc USA. Neutralizowanie wpływów amerykańskich jest ważnym celem polityki chińskiej. Drugim istotnym czynnikiem może być poparcie Moskwy dla ewentualnej chińskiej ,interwencji w obronie integralności państwa”. Należy przy tym zwrócić uwagę, że zawsze, nawet w okresie wrogości w relacjach wzajemnych, ZSRR opowiadał się za całością terytorialną Chin.

7 China's Position on Establishing a New International Political and Economic Order, http:// www.fmprc.gov.cn/eng/wjdt/wjzc/t24883.htm [dostęp 5.02.2011].

8 China's Views on the Development of Multipolarization, http://www.fmprc.gov.cn/eng/wjdt/ wjzc/t24880.htm [dostęp 5.02.2011]. 
Wymienione zasady były niejednokrotnie doprecyzowywane i uzupełniane $\mathrm{w}$ zależności od zmieniających się wydarzeń międzynarodowych. Podczas ostatniego spotkania prezydentów Hu Jintao i Dmitrija Miedwiediewa w kwietniu 2011 r. wymieniono podstawowe zasady, jakimi kierują się obie strony przy rozwiązywaniu problemów międzynarodowych. Zaliczono do nich: niemieszanie się w sprawy wewnętrzne innych państw oraz nieuciekanie się do siłowych akcji przy rozwiązywaniu problemów globalnych, takich jak: problem koreański (preferencje dla rozmów sześciostronnych), bliskowschodni i Północnej Afryki. Jednoznacznie wyrażono sprzeciw dla ingerencji w procesy wewnętrzne w regionach (Chiny osiągnęly zrozumienie Rosji dla swojej krytyki mieszania się USA w spory bilateralne z państwami regionu Azji Południowo-Wschodniej, w tym o archipelagi Spratly i Paracele) i państwach, mając na uwadze świat arabski. Strony zgodziły się również w kwestii budowy regionalnego bezpieczeństwa i współpracy charakteryzującej się „otwartością, transparentnością i równością", a także uzgodniły multilateralny mechanizm gwarantowania pokoju i bezpieczeństwa w regionie Azji Północno-Wschodniej. W deklaracji wyrażono przekonanie, że ,partnerstwo strategiczne” będzie kluczowym czynnikiem pozwalającym zbudować pokój i bezpieczeństwo w regionie.

Podsumowując ten wątek rozważań, warto przytoczyć opinię profesora Wang Haiyun, wiceprzewodniczącego Chińskiego Towarzystwa Studiów Historii Stosunków Chińsko-Rosyjskich, który powiedział, że ustanowienie i rozwój współpracy strategicznej między oboma krajami jest oparty i rozwija się na bazie wspólnych interesów strategicznych, ale jednocześnie wspólnej koncepcji stosunków międzynarodowych (użył pojęcia kultury strategicznej) ${ }^{10}$. Do tych elementów badacz zalicza takie wartości, jak: wspólne zaufanie i szacunek, obopólne korzyści ze współpracy oraz niemieszanie się w sprawy innych państw, nieantagonizowanie ich i szacunek dla wszystkich krajów. Kolejna wartość to podobne założenia modernizacyjne: rosyjska „suwerenna demokracja” i „kontrolowalna gospodarka rynkowa” są podobne do ,demokracji socjalistycznej” i ,socjalistycznej gospodarki rynkowej z chińską charakterystyką". Trzeci segment to budowa świata wielobiegunowego i sprzeciw wobec hegemonii, demokratyzacja stosunków międzynarodowych, poszanowanie dla różnorodności cywilizacyjnej, ustanowienie racjonalnej polityki międzynarodowej i porządku gospodarczego ${ }^{11}$. Wymienione przesłanki, wynikające ze wspólnych interesów regionalnych i globalnych, jak również postrzegania rzeczywistości międzynarodowej, nie są jedynymi, które determinują cele polityki chińskiej wobec Rosji. Spośród pozostałych podkreślić należy wagę czynnika energetycznego dla zabezpieczenia stabilnego

9 „China Daily”, 17.06.2011.

10 Ibidem.

11 Wang Haiyun, Russia's Strategic Value to China, http://www.fmprc.gov.cn/eng/wjb/zzjg/ dozys/gjlb/3220/ [dostęp 2.10.2012]. 
rozwoju gospodarczego Państwa Środka oraz współpracy technologiczno-militarnej. Jak stwierdza Alexandr Nemets, wszystkie te cele są komplementarne oraz synergiczne i ,dlatego nie ma w tym nic dziwnego, że relacje dwustronne Moskwy i Pekinu ulegają stałej poprawie"12.

\section{Instytucjonalizacja relacji z Rosją}

Stosunki chińsko-radzieckie zaczęly ulegać poprawie na początku lat 80 . ubiegłego wieku, mimo że Chiny wciąż sprzeciwiały się stacjonowaniu wojsk radzieckich wzdłuż granicy chińsko-radzieckiej i w Mongolii, a także protestowały wobec interwencji w Afganistanie. Jako warunek wstępny rozmów wysunęły wycofanie tych wojsk z wymienionych terytoriów.

We wrześniu 1984 r. wicepremier ZSRR Iwan Archipow odwiedził Pekin i rozmawiał ze swoim odpowiednikiem Li Peng'iem. Co prawda, nie osiągnięto wówczas żadnego konkretnego porozumienia, ale atmosfera relacji dwustronnych wyraźnie weszła w fazę odwilży. Jednak dopiero pieriestrojka dała impuls do wznowienia kontaktów wzajemnych. W czerwcu $1985 \mathrm{r}$. zawarto pierwszą długoterminową umowę o handlu i płatnościach, w 1987 r. sześć rosyjskich uczelni podpisało porozumienie o bezpośrednich kontaktach, a w grudniu 1988 r. do Moskwy przybył minister spraw zagranicznych ChRL (pierwszy raz od 1957 r.) ${ }^{13}$. Strony sformułowały również dziewięciopunktowe oświadczenie w sprawie Kambodży i uzgodniły wizytę sekretarza generalnego KPZR Michaiła Gorbaczowa w Chinach w dniach 15-18 maja 1989 r. Na atmosferę wizyty wpływ miały wydarzenia na placu Tian'anmen. Założony cel został jednak osiągnięty i drugiego dnia pobytu Deng Xiaoping odbył historyczne spotkanie z Gorbaczowem. Deng podkreślał, że klucz do dwustronnych relacji leży we wzajemnym równym traktowaniu się. Stwierdził, że Chiny nie są zagrożeniem dla swoich sąsiadów i nie chcą czuć zagrożenia ze strony innych państw. Wspominał również okres słabości Chin i imperializmu państw europejskich oraz trudne lata w relacjach między ZSRR i Chinami. Obaj liderzy zgodzili się, że czas rozpocząc nowy etap we wspólnych relacjach, zrobić konkretne kroki w kierunku wzajemnie korzystnej współpracy i zostawić przeszłość za sobą. W uzgodnionym komunikacie znalazło się stwierdzenie, że obie strony chcą stosunków nowego typu ${ }^{14}$.

12 A. Nemets, Russia and China. The Mechanics of an Anti-American Alliance, „Journal of International Security Affairs" 2006, no. 11, http://www.securityaffairs.org/issues/2006/11/nemets. php [dostęp 11.10.2012].

13 W. Dacyszen, Kitajcy w Sibiri $w$ XVII-XX w.: problemy migracyi i adaptacyi, SFU, Krasnojarsk 2008, s. 269.

14 „End the Past and Open Up the Future”. The Normalization of Relations between China and the Soviet Union, http://www.fmprc.gov.cn/eng/ziliao/3602/3604/t18018.htm [dostęp 2.05.2010]. 
Uzgadnianie zasad stosunków dwustronnych Rosji i Chin przypadło na lata 1990-1997. Po rozpadzie ZSRR, w grudniu 1992 r. prezydent Rosji po raz pierwszy odwiedził Chiny. Ważnym rezultatem wizyty było podpisanie Deklaracji o zasadach stosunków wzajemnych, która wypełniła lukę po Traktacie o przyjaźni i współpracy, podpisanym jeszcze w 1950 r. ${ }^{15} \mathrm{~W} 1994$ r. prezydent Jiang Zemin udał się z rewizytą do Moskwy, gdzie oba państwa opowiedziały się za „strategicznym i konstruktywnym partnerstwem, opartym na podstawowych zasadach pokojowego współistnienia". Jednocześnie obie strony zaakcentowały prawo do wyboru własnej drogi i modelu rozwojowego ${ }^{16}$.

W czerwcu 1995 r. do Rosji przyjechał z wizytą premier Li Peng. Obaj premierzy, Li Peng i Wiktor Czernomyrdin, podpisali pakiet ośmiu dokumentów na temat współpracy gospodarczej. Zawarto umowę ekstradycyjną oraz w sprawie wymiany informacji.

Obecnie podstawową zasadą współpracy obu krajów jest odideologizowanie stosunków wzajemnych i oparcie ich o ideę ,partnerstwa strategicznego w XXI w.", która została wypracowana na szczycie obu państw w kwietniu 1996 r., w czasie wizyty prezydenta Jelcyna w Chinach, i wpisana do deklaracji końcowej. Zaznaczono w niej, że celem współpracy jest utrzymanie stabilności regionalnej, podkreślono również, że nie jest ona skierowana przeciw żadnemu innemu państwu. Prezydent Jiang Zemin nazwał te relacje mianem ,ani sojuszu, ani konfrontacji”, ale równouprawnienia i wzajemnych korzyści ${ }^{17}$.

Współpracę tę umożliwiło porozumienie w sprawie liczącej $4280 \mathrm{~km}$ granicy. Odcinek wschodni został uzgodniony jeszcze w okresie istnienia ZSRR - 16 maja $1991 \mathrm{r}$. w Moskwie podpisano porozumienie w sprawie przebiegu granicy radziecko-chińskiej na jej wschodnim odcinku. Ostatecznie problemy graniczne uzgodniono w czasie wizyty Borysa Jelcyna w Chinach w dniach 8-9 listopada 1997 r. Na całym odcinku wschodnim, na terenie Zabajkala i Przymorza ustawiono 1182 słupy graniczne ${ }^{18}$. Największy problem stanowił rejon ujścia rzeki Ussuri do Amuru i wyspy na tych rzekach. Chiny i Rosja podzieliły je między sobą. Na konferencji w dniu 14 października 2004 r. rozwiązano kwestie trzech ostatnich wysp: Bolszoj Ussurijskij, Tarabarow oraz Bolszoj na rzece Argun ${ }^{19}$. Tarabarow przypadł Chinom, Bolszoj Ussurijskij i Bolszoj na rzece Argun podzielono między Chiny i Rosję.

15 D. Mierzejewski, Rosja-Chiny. Próba charakterystyki wspótpracy w latach dziewięćdziesiatych, [w:] Rosja między wspótczesnością a historia, pod red. A. Głowackiego i A. Stępień, Łódź 2002, s. 180.

16 Ibidem, s. 181.

17 B. Rychłowski, Stosunki Chiny-Rosja w okresie transformacji, [w:] Rosja-Chiny. Dwa modele transformacji, red. E. Wielgosz, Wydawnictwo Adam Marszałek Toruń 2000, s. 28-29.

18 D. Mierzejewski, op. cit., s. 182.

19 A. Iwasita, 4000 kitomietrow problem. Rossijsko-kitajskaja granica, AST, Moskwa 2006. 
23 listopada 1998 r. odbyło się nieoficjalne spotkanie przywódców Chin i Rosji. Strony przyjęły oświadczenie o stosunkach rosyjsko-chińskich u progu XXI stulecia, potwierdzające wolę budowy wielobiegunowego ładu międzynarodowego. Oba państwa konsekwentnie sprzeciwiały się obcym ingerencjom w sprawy wewnętrzne. Na zakończenie wizyty uzgodniono stały mechanizm spotkań i konsultacji. Druga półoficjalna wizyta Jelcyna w Pekinie miała miejsce w grudniu 1999 r. W komunikacie z tego spotkania potwierdzono znaczenie deklaracji o partnerstwie strategicznym oraz wolę wspólnych działań przeciw wszelkim zagrożeniom dla globalnej stabilności. Rosja m.in. poparła chińskie działania w sprawie Tajwanu, a z kolei Chiny - rosyjskie rozwiązania zwalczające separatyzm czeczeński. Szczególnie mocno wybrzmiało wspólne stanowisko potępiające świat jednobiegunowy, ujednolicenie modelu kultury, forsowanie jedynie słusznych wartości świata Zachodu i instrumentalne wykorzystywanie praw człowieka w imię interwencji w sprawy wewnętrzne innych państw, zastępowanie prawa międzynarodowego polityką mocarstw ${ }^{20}$.

Za konieczną uznano również synchronizację wspólnych działań na poziomie dwustronnym i wielostronnym, podkreślono przy tym znaczenie nowej multilateralnej struktury - Szanghajskiej Piątki zapisanej w Deklaracji w Biszkeku. W ciągu lat 90. między Rosją i Chinami doszło do 24 wizyt na wysokim szczeblu²1.

W latach 2000. prezydenci kontynuowali spotkania, które odbywały się nawet kilka razy w roku. W relacjach wzajemnych ważny był rok 2001, kiedy podpisano Układ o dobrym sąsiedztwie i współpracy wzajemnej. Symboliczną pierwszą wizytę jako prezydent Dmitrij Miedwiediew złożył w Chinach w dniach 23-24 maja 2008 r. Strony podpisały wspólną deklarację, w której powtórzono slogany o uznaniu różnorodności kulturowej w ramach społeczności międzynarodowej i tworzeniu świata wielobiegunowego ${ }^{22}$. Lata 2008-2009 to jednak początek kryzysu gospodarczego, co w relacjach dwustronnych odbiło się wzrastającą nierównowagą handlową.

Oprócz wizyt oficjalnych prezydent Hu Jintao odwiedził Rosję w czerwcu 2009 r. Spotkania na najwyższym szczeblu odbywały się przy okazji szczytów G8, APEC, SCO (spotkania bilateralne) oraz BRICS (np. w Jekaterinburgu w czerwcu 2009 r.) i G20.

Obie strony przyjęły Plan działań na lata 2009-2012, które miały służyć realizacji postanowień Układu o współpracy. Dialog energetyczny zszedł na poziom wicepremierów i stał się bardziej elastyczny. Jeśli chodzi o sferę inwestycyj-

20 Sino-Russian Joint Statement, http://www.fmprc.gov.cn/eng/wjb/zzjg/dozys/gjlb/3220/3221/ t16727.htm [dostęp 20.02.2010].

21 D. Mierzejewski, op. cit., s. 182.

22 V. Portyakov, Russian-Chinese Relations: Current Trends and Future Prospects, „Russian Analitic Digest” 2010, no. 73, on-line, http://www.css.ethz.ch/publications/pdfs/RAD-73.pdf. 
ną, to w czerwcu 2009 r. strony uzgodniły plan współpracy rosyjsko-chińskiej, a we wrześniu 2009 r. program współpracy między regionami Rosyjskiego Dalekiego Wschodu i Wschodniej Syberii a Chińskim Północnym Wschodem na lata 2009-2018, włączając w to przemysł wydobywczy, produkcję przemysłową i transport.

W 2010 r. Chiny i Rosja uroczyście obchodziły 60. rocznicę nawiązania stosunków dyplomatycznych. W związku z tym zorganizowano wiele imprez. Prezydenci Hu Jintao i Dmitrij Miedwiediew otwierali uroczystości w Moskwie, a premierzy Władimir Putin i Wen Jiabao w Pekinie ${ }^{23}$.

W roku 2010 prezydenci obu krajów spotkali się sześć razy: w czasie obchodów 65. rocznicy zwycięstwa i zakończenia II wojny światowej (Wielkiej Wojny Ojczyźnianej), na szczycie przywódców BRICS w Brazylii, Szanghajskiej Organizacji Współpracy w Taszkiencie, szczycie G20 w Toronto, w czasie rozmów sześciostronnych, a w dniach 26-28 września prezydent Rosji przebywał w Chinach z wizytą w czasie wystawy EXPO w Szanghaju. Symptomatyczna była również ostatnia wizyta, jaką Wen Jiabao złożył jako premier. W grudniu 2012 r. spotkał się w Moskwie z premierem Miedwiediewem oraz w Soczi z prezydentem Putinem. Oprócz części dotyczącej współpracy energetycznej, gospodarczej, naukowo technicznej, humanitarnej i militarnej, ważnym tłem rozmów była zmiana warty na najwyższych stanowiskach państwowych po XVIII Zjeździe KPCh i kontynuacja strategicznych relacji z Rosją.

\section{Udział w strukturach wielostronnych}

Chiny i Rosja uzgadniają swoje stanowiska w ważnych zagadnieniach międzynarodowych, takich jak: reforma Rady Bezpieczeństwa ONZ, globalne zarządzanie gospodarką, zmiany klimatyczne, bezpieczeństwo żywnościowe i energetyczne, czy też aktualne problemy regionalne, np. Półwyspu Koreańskiego, badań nuklearnych w Iranie czy konfliktu afgańskiego i sytuacji w Syrii. Koordynacja działań jest możliwa dzięki ścisłej współpracy dwustronnej, ale także w ramach mechanizmów wielostronnych, w tym takich jak ONZ, SOW, grupa G20, APEC czy też od niedawna BRICS.

\section{Szanghajska Organizacja Wspólpracy}

Analizę procesu tworzenia mechanizmów wielostronnych współdziałania obu partnerów należy rozpocząć od Porozumienia szanghajskiego. Działająca obecnie Szanghajska Organizacja Współpracy powstała jako Szanghajska Piątka

23 Zhao Huasheng Sino-Russian Relations 2009 to 2010: A Perspective from China, „Russian Analitic Digest" 2010, no. 73, s. 5. 
w roku 1996, a oprócz Chin i Rosji tworzyły ją również: Kazachstan, Kirgistan i Tadżykistan. 26 kwietnia 1996 r. strony podpisały Umowę o umocnieniu środków zaufania w kwestiach wojskowych na obszarze pogranicza. Szanghajska Organizacja Współpracy była też próbą poszukiwania formuły długofalowej współpracy. Państwa chciały zbalansować obecność amerykańską w regionie Azji Środkowej. W 1997 r. strony podpisały Deklarację rosyjsko-chińską o świecie wielobiegunowym oraz budowie nowego porządku światowego. Była to pierwsza wspólna deklaracja podkreślająca znaczenie świata wielobiegunowego i wypowiadająca się przeciw amerykańskiej hegemonii.

W roku 2001 organizacja została przekształcona w Szanghajską Organizację Współpracy (Shanghai Cooperation Organization - SCO), do grona pięciu państw dołączył Uzbekistan. Iran, Mongolia, Indie i Pakistan posiadają status obserwatora, Białoruś i Sri Lanka - partnerów dialogu, a ASEAN, CIS i Turkmenistan - zapraszanych gości. Potencjał państw członkowskich jest ogromny - $30 \mathrm{mln} \mathrm{km}^{2}$, czyli $60 \%$ obszaru Euroazji oraz $25 \%$ populacji świata. W kontekście „zderzenia cywilizacji” warto zwrócić uwagę na fakt, że w SCO znalazło miejsce pięć niezachodnich cywilizacji: rosyjska (prawosławna), chińska (konfucjańska), muzułmańska, hinduistyczna oraz buddyjska ${ }^{24}$. Organizacja rozszerzała swoje cele: te związane z bezpieczeństwem oraz współpracą militarną zostały uzupełnione przez cele ekonomiczne. W 2005 r. na szczycie moskiewskim sekretarz generalny SCO stwierdził, że priorytetem gospodarczym dla jej członków będą projekty w sektorze energetycznym, w tym: eksploatacja ropy i gazu oraz hydroenergetyka i gospodarka wodna. $Z$ punktu widzenia interesów chińskich postawiony cel jest niezwykle ważny, ponieważ stabilizuje i zabezpiecza „politycznie" dostawy ropy i gazu z rosyjskiej Syberii oraz Azji Środkowej. Współpraca w ramach SCO stwarza możliwość realizacji podstawowych celów, globalnej strategii - stworzenia świata wielobiegunowego. Państwa SCO mają realną szansę zagwarantowania bezpieczeństwa regionu Azji Centralnej i „wyproszenia” stamtąd zachodnich potęg ${ }^{25}$. W listopadzie 2005 r. Siergiej Ławrow zwrócił uwagę na ten aspekt strategii SCO: „Szanghajska Organizacja Współpracy działa w kierunku zbudowania racjonalnego i sprawiedliwego porządku światowego [...] Daje nam niepowtarzalną możliwość wzięcia udziału $\mathrm{w}$ procesach formułowania fundamentalnie nowego modelu geopolitycznej integracji”'26. Również w 2005 r., w przyjętej deklaracji, członkowie wyraźnie dali do zrozumienia, że pora wycofać się z Afganistanu, ponieważ SCO ma realną siłę, by obronić bezpieczeństwo regionu ${ }^{27}$.

\footnotetext{
${ }^{24}$ http://rickrozoff.wordpress.com/2009/08/29/150/ [dostęp 15.11.2010].

25 „People's Daily”, 8.07.2005.

26 UzReport, 28.11.2005.

27 „People's Daily”, 8.07.2005.
} 


\section{BRICS}

Powstanie BRIC (Brazylia, Rosja, Indie i Chiny) należy rozpatrywać z punktu widzenia tworzenia nowego systemu międzynarodowego i zwiększenia roli niezachodnich państw rozwijających się w procesie globalizacji. Państwa BRIC po raz pierwszy zebrały się na szczeblu ministrów spraw zagranicznych w czasie sesji Zgromadzenia Ogólnego ONZ w roku 2006, a w kwietniu 2011 r. do organizacji dołączyła Republika Południowej Afryki, stąd pojawiła się uzupełniona nazwa grupy. Poprzez BRICS Chiny starają się wzmocnić niedoreprezentowane do tej pory $\mathrm{w}$ organizacjach międzynarodowych państwa rozwijające się. $\mathrm{W}$ deklaracji przyjętej na szczycie w Sanya (Chiny, prowincja Hainan) zostały zapisane zasady polityki zagranicznej, które odwołują się do haseł nawiązujących do zasad polityki zagranicznej promowanych do tej pory przez Chiny. W punkcie 4. deklaracji mówi się o większej harmonii, współpracy i rozwoju naukowym w XXI w. Pojawily się tu również inne stwierdzenia, które wcześniej znajdowały się w dwustronnych deklaracjach chińsko-rosyjskich: dążenie BRICS do odgrywania większej roli w budowaniu pokoju światowego, bezpieczeństwa i stabilnego wzrostu ekonomicznego, wzmocnienia multilateralizmu, promowania większej demokratyzacji stosunków międzynarodowych. Chiny i Rosja opowiedziały się za koniecznością odgrywania większej roli w Organizacji Narodów Zjednoczonych Indii, Brazylii i Republiki Południowej Afryki oraz za reformą Narodów Zjednoczonych, choć w deklaracji nie znalazły się konkretne stwierdzenia dotyczące poszerzenia składu stałych członków RB.

Delegacje wypowiedziały się ponadto za reformą Międzynarodowego Funduszu Walutowego i zwiększeniem roli G20 oraz przeobrażeniami w międzynarodowych strukturach finansowych, które muszą odzwierciedlać zmiany w grupie państw rozwijających się i ich nową rolę ${ }^{28}$. Szczyt w Sanya w sposób niebudzący wątpliwości postawił kwestię zmiany konfiguracji współczesnego świata, co jest zgodne z celami polityki chińskiej. Ten alternatywny świat to taki, gdzie wartością są różne typy aktywności i postawienie nie na egoistyczne a globalistyczne podejście do rozwiązywania problemów światowych. Umiar w korzystaniu z zasobów naturalnych i poskromienie apetytów konsumpcyjnych będą miały wpływ na zbudowanie nowego modelu świata różnorodnego, a nie ,jednoreligijnego, usankcjonowanego przez unipolarny porządek światowy"29. Najpoważniejszym partnerem BRICS jest Szanghajska Organizacja Współpracy.

\section{Rada Bezpieczeństwa ONZ}

Kwestia koordynowania polityki zagranicznej i wypracowania wspólnego stanowiska wobec różnych problemów światowych znalazła już odzwierciedlenie

28 http://news.xinhuanet.com/english2010/china/2011-04/14/c_13829453_9.htm [dostęp 10.10.2012].

${ }^{29}$ L. Ivashov, BRICS and the Mission of Reconfiguring the World, http://en.interaffairs.ru/ read.php?item=203 [dostęp 10.10.2012]. 
w głosowaniach w Radzie Bezpieczeństwa. Przykłady to wspólne stanowisko w sprawie Birmy w 2007 r., w sprawie pokoju w Afryce (Zimbabwe) w 2008 r., trzykrotne weto w sprawie Syrii w latach 2011-2012.

Chiny oficjalnie postulują zmiany idące w kierunku większej reprezentatywności geograficznej Rady Bezpieczeństwa oraz państw rozwijających się, a także większej transparentności $\mathrm{w}$ procesie podejmowania decyzji, w tym wysłuchania państw niebędących członkami RB. Stoją na stanowisku, że w procesie przygotowywania reform udział powinny mieć różne grupy państw ${ }^{30}$. Rosja popiera kierunek związany z większą reprezentatywnością RB, w tym bierze pod uwagę aspiracje takich państw, jak: Indie, Brazylia, Niemcy, Japonia, Południowa Afryka i Egipt, ale relacje między starymi i nowymi członkami stałymi RB wymagałyby kompromisu ${ }^{31}$. Największą niechęć Chin budzi ewentualna obecność Japonii wśród stałych członków RB, a argumentem, który najczęściej przywołują, jest nierozliczenie się tego państwa ze swoich zbrodni z okresu II wojny światowej. W czasie szczytu BRICS w 2011 r. Chiny i Rosja wyraźnie poparły Indie, Brazylię i Południową Afrykę w ich staraniach o stałe członkostwo w RB i odgrywanie bardziej znaczącej roli międzynarodowej ${ }^{32}$.

\section{APEC}

APEC (Asia Pacific Economic Cooperation, Rada Współpracy Gospodarczej Azji i Pacyfiku, powstała 12 listopada 1989 r.) wiąże region w stosunkach międzynarodowych. 12 listopada 1991 r., na szczycie APEC odbywającym się w Seulu, Chiny, Tajwan i Hongkong zostały jednogłośnie przyjęte do tej organizacji.

W listopadzie 1998 r. delegacja rosyjska, na czele której stał premier Jewgienij Primakow, po raz pierwszy wzięła udział w szczycie państw APEC i chociaż wydarzenie to bardziej podkreślało znaczenie stabilnej Rosji dla utrzymania równowagi sił w regionie niż rzeczywiste możliwości tego państwa, miało znaczenie polityczne. Obecnie gospodarki APEC (21 państw członkowskich) stanowią ponad połowę światowego PKB oraz $44 \%$ wymiany towarowej. Właśnie aktywne kontakty handlowo-gospodarcze pozwalają większości państw tego regionu na skuteczne pokonanie skutków światowego kryzysu finansowego.

Chiny popierały członkostwo Rosji w APEC. Współpraca tych państw $\mathrm{w}$ ramach organizacji pomaga zrealizować niektóre cele związane $\mathrm{z}$ większą integracją Syberii i Rosyjskiego Dalekiego Wschodu, co jest korzystne dla Pekinu. W roku 2012 rotacyjne przewodnictwo przejęła Rosja, a szczyt APEC odbył się we Władywostoku. Przewodnictwo rosyjskie było okazją do pogłę-

${ }_{30}$ China and Security Council Reform, http://www.fmprc.gov.cn/eng/wjb/zzjg/gjs/gjzzyhy/2594/2595/t15136.htm [dostęp 2.10.2012].

31 http://en.rian.ru/russia/20080123/97602972.html [dostęp 18.11.2010].

32 BRICS Nations Call for UN Security Council Reform, http://www.channelnewsasia.com/ stories/afp_world/view/1122790/1/.html [dostęp 10.10.2012]. 
bionej integracji regionów azjatyckich Rosji oraz budowy infrastruktury, która sprzyjałaby ściślejszym kontaktom - w tym wypadku chodziłoby o obszary graniczne Rosji i Chin. W Chinach są to: Heilongjiang, Mongolia Wewnętrzna, Jilin i fragmenty Liaoning na północnym wschodzie oraz rejon Ałtaju w Xinjiangu na północnym zachodzie. Koncepcja co-development leży w interesie tych prowincji, bo regiony te będą mogły się rozwijać nie tylko dzięki umowom na szczeblu centralnym, ale również korzystając z uzgodnień regionalnych, co może wzmocnić autonomię regionów nadgranicznych. Kamieniem milowym takiego podejścia był opracowany w 2009 r., wspominany już, wspólny program współpracy między Rosyjskim Dalekim Wschodem i Wschodnią Syberią a północno-wschodnimi Chinami. Program ma dotyczyć lat 2009-2018 i zdaniem analityków, ,jest o wiele ważniejszy dla chińskich niż dla rosyjskich regionów" ${ }^{\prime 3}$. W kontekście współpracy w ramach APEC szczególnie ważna jest budowa infrastruktury transportowej. Strony uzgodniły budowę szybkiej kolei między rosyjskim Ałtajem i chińskim Ałtajem w Xinijangu. Drugą inwestycją ma być budowa mostu przez rzekę Amur, mającego połączyć Błagowieszczeńsk z chińskim Heihe.

Szczyty APEC są również okazją do uzgodnień dwustronnych. Dla Chin dobra współpraca z Rosją w ramach organizacji stwarza możliwość wypracowania wspólnego stanowiska np. w sprawie amerykańskich prób wydzielenia (bez udziału Chin) Transpacific Strategic Economic Partnership, zaproponowanego przez delegację amerykańską na szczycie APEC w Honolulu w 2011 r. Pozwala też „przeciągnąć” Rosję na swoją stronę w kontekście rywalizacji amerykańskochińskiej w regionie.

\section{ASEAN}

Ani Rosja, ani Chiny nie są członkami ASEAN (Stowarzyszenie Narodów Azji Południowo-Wschodniej), ale Chiny są członkiem ASEAN+3 (zainicjowane w 1997 r.) oraz pełnoprawnym partnerem dialogu od 1996 r.; w tym samym roku status partnera dialogu otrzymała Rosja. Od 1994 r. ASEAN podjął wiele inicjatyw związanych z umacnianiem systemu bezpieczeństwa regionalnego. W $1994 \mathrm{r}$. powstało Forum Regionalne (ARF), w którym obok dawnych członków tej organizacji (Brunei, Indonezji, Malezji, Singapuru, Tajlandii, Filipin i Wietnamu) uczestniczą także: Rosja, USA, Chiny, Japonia, Indie, Republika Korei, Australia, Nowa Zelandia, Kambodża, Mongolia i jako członek zbiorowy - Unia Europejska. Forum nakreśliło szereg zadań związanych z umacnianiem pokoju, bezpieczeństwa i stabilności, służących rozwojowi gospodarczemu w regionie.

33 O. Barabanov, Three Bridges and One Road: Siberia, Far East and China, http://indrus.in/ articles/2011/06/10/three_bridges_and_one_road_siberia_far_east_and_china_12628.html [dostęp 10.01.2013]. 


\section{EAS}

Perspektywiczną inicjatywą ASEAN+3 było zwołanie Szczytu Wschodnioazjatyckiego (East Asian Summit - EAS) w Kuala Lumpur w grudniu 2005 r. W spotkaniu, obok 10 państw-członków ASEAN, uczestniczyły również: Chiny, Japonia, Republika Korei, Australia, Nowa Zelandia i Indie oraz jako obserwator Rosja. Takie forum mogło potencjalnie zastąpić APEC, jeśli chodzi o cele związane z liberalizacją handlu oraz inwestycji, jak również integracji regionalnej. Co ciekawe, EAS powstało bez udziału tradycyjnego gracza w regionie - USA, inicjującą rolę odegrały tu Chiny. Organizacja jest traktowana jako kontynuacja wcześniejszej inicjatywy wysuniętej przez premiera Malezji Mahathira Bin Mohameda East - Asia Economic Caucus, która była skierowana jedynie do państw azjatyckich. Dla Chin EAS nie tylko służy liberalizacji gospodarczej w regionie, ale stwarza również możliwość eksponowania i realizowania celów polityki zagranicznej. Pekin zademonstrował zdolność do tworzenia realnych i konstruktywnych podstaw integracji w kontekście zarówno regionalnym, jak i globalnym. Delegacje przyjęły deklarację określającą spotkanie jako forum dialogu dotyczącego wszystkich ważnych spraw regionu $\mathrm{w}$ imię umacniania pokoju, stabilności i rozwoju gospodarczego w Azji Wschodniej. Zaznaczono w niej również, że szczyt może odegrać znaczącą rolę w budowie Wspólnoty Azji Wschodniej (East Asia Community).

W roku 2011, w szóstym szczycie EAS w Indonezji - już jako pełnoprawni członkowie - uczestniczyły delegacje USA i Rosji. Stany Zjednoczone, które geograficznie nie są członkami regionu, ale są ważnym graczem, oraz Rosja, ze swoimi bogactwami naturalnymi, co prawda, nie cywilizacyjnie, ale geopolitycznie są potrzebne gospodarczo w procesie integracji. Minister spraw zagranicznych Chin Yang Jiechi, odnosząc się do przyjęcia Rosji i USA do grona państw EAS, stwierdził, że nadal najważniejszymi celami organizacji będą rozwój i współpraca w takich dziedzinach, jak: edukacja, finanse, energia, zdrowie, zarządzanie kryzysowe, bezpieczeństwo żywnościowe. Powtórzył, jakie wartości leżą u podstaw polityki zagranicznej Chin: wzajemne zaufanie oraz rozwiązywanie sporów metodami pokojowymi ${ }^{34}$.

Chiny i Rosja współpracują również w czasie rozmów sześciostronnych w sprawie Korei. Dla Rosji udział w negocjacjach jest ,powrotem do gry”, częścią jej azjatyckiej strategii budowy systemu bezpieczeństwa w Azji. Moskwa popiera Chiny, które nie zgadzają się na nałożenie surowych sankcji przeciw Korei Północnej. Istnienie tego kraju jest ważne dla Chin, ponieważ stanowi on bufor bezpieczeństwa przed wojskami amerykańskimi stacjonującymi w Korei Południowej. Jednocześnie wsparcie humanitarne i gospodarcze reżimu północnokoreańskiego może uchronić Pekin i Seul przed możliwą falą uciekinierów.

34 http://news.xinhuanet.com/english2010/video/2011-07/23/c_131004341.htm [dostęp 15.12.2012]. 
Działania wielostronne uzupełniły inicjatywy dwustronne, których głównym celem było zagwarantowanie stabilności. Proces modernizacji gospodarek oraz przekształcenie rosyjskiego i chińskiego społeczeństwa ma niewątpliwie największy wpływ na wzajemne relacje. Stosunki dwustronne rysowały się dla obu państw jednocześnie zarówno jako pełne perspektyw, jak i ryzyka. Przywołując zdanie wypowiedziane przez Alekseja Bogutarowa, wicedyrektora Instytutu Problemów Bezpieczeństwa Rosyjskiej Akademii Nauk, „Chiny to morze potencjalnych możliwości i ocean obaw"35.

\section{Narzędzia militarne i wspólpraca wojskowa}

Zwrot w stosunkach dwustronnych, zapoczątkowany w drugiej połowie lat 80. XX w., zaowocował rozwojem współpracy w dziedzinie militarnej i wojskowej. W maju 1991 r. do Pekinu udał się z wizytą minister obrony ZSRR, Jewgienij Szaposznikow. Obie strony przyznały, że nie stanowią dla siebie zagrożenia. W czasie rewizyty ministra Qin Jiwei w Moskwie politycy omawiali problem dyslokacji wojsk w rejonach przygranicznych oraz redukcji obecności militarnej na Dalekim Wschodzie. Strony zgodziły się na konsultacje wojskowe na wysokim szczeblu, wzajemne informowanie się o przemieszczaniu wojsk w strefie przygranicznej, a także współpracę granicznych jednostek wojskowych ${ }^{36}$. W maju $1994 \mathrm{r}$. wizytę we Władywostoku złożyli przedstawiciele Floty Północnej Chińskiej Armii Ludowo-Wyzwoleńczej, a następnie do Qingdao udali się przedstawiciele Rosyjskiej Floty Oceanu Spokojnego.

Podczas spotkania w lipcu 1994 r. Chi Haotian i Paweł Graczow podpisali Porozumienie w sprawie zapobiegania niebezpiecznej działalności wojskowej pomiędzy rządami Chin i Rosji. Planowano zabezpieczenie przed przypadkowo wystrzelonymi pociskami balistycznymi, zaprzestanie wzajemnego zagłuszania urządzeń łączności, stworzenie systemu wczesnego reagowania, który informowałby o nieumyślnym naruszeniu granic, a także zakazano stosowania laserów szkodliwych dla wzroku. Kolejna wizyta premiera Primakowa w Pekinie w roku 1996 przyniosła postęp, jeśli chodzi o sprzedaż broni, ale również zgodę na koordynację polityk na wielu polach w reakcji na amerykańskie plany rozmieszczenia defensywnych pocisków balistycznych ${ }^{37}$. Obie strony próbowały ograniczyć możliwość wzajemnego ataku. W kwietniu tego roku podpisano porozumienie w Szanghaju, w którym zapewniono, że:

35 P. Ferdinand, Sunset, Sunrise: China and Russia Construct a New Relationship, „International Affairs" 2007, no. 5, s. 841.

36 D. Mierzejewski op. cit., s. 183-184.

37 A. Nemets, Russia and China. The Mechanics of an Antiamerican Alliance, „The Journal of International Security Affairs", nr 11, 2005, http://www.securityaffairs.org/issues/2006/11/ nemets.php [dostęp 11.10.2012]. 
1. Przemieszczane oddziały graniczne nie będą prowadziły działań zbrojnych przeciwko sobie.

2. Ćwiczenia wojskowe nie będą wymierzone przeciwko żadnej ze stron.

3. Skala, zasięg, miejsce i liczebność oddziałów wojskowych biorących udział w ćwiczeniach będzie ograniczona.

4. Ważniejsze posunięcia militarne w promieniu ok. $100 \mathrm{~km}$ od granicy wymagały będą poinformowania się obu stron.

5. W pewnych okolicznościach w manewrach wojskowych będą brali udział obserwatorzy.

6. Strona rosyjska i chińska miały dołożyć wszelkich starań w celu uniknięcia niebezpiecznych incydentów, ponadto zapewniono o przyjaznej wymianie między siłami zbrojnymi ${ }^{38}$.

Podpisanie umów granicznych pozwoliło na przegrupowanie wojsk ochrony pogranicza: rosyjskich do Europy, a chińskich w rejon Cieśniny Tajwańskiej. Dodatkowo powołanie do życia Szanghajskiej Piątki i realizacja jej celów - budowy systemu wzajemnego zaufania dała pozytywne rezultaty. W 1997 r. chiński prezydent spotkał się prezydentami Rosji, Kazachstanu, Tadżykistanu oraz Kirgistanu i osiągnięto porozumienie w sprawie wzajemnej redukcji wojsk w rejonach przygranicznych. Ważną decyzją strony rosyjskiej było umożliwienie Chińczykom studiowania na wyższych uczelniach przy Rosyjskim Ministerstwie Obrony.

W okresie sierpień 1999 r. - lipiec 2001 r. strategiczna współpraca między obu państwami przyniosła kontrakty na sprzedaż broni i technologii na kwotę co najmniej 2 mld USD, jak również inicjatywę wspólnych manewrów wojskowych obu armii. W czasie pobytu w Duszanbe w czerwcu 2000 r. prezydent Putin obiecał Jiang Zeminowi, że w razie konfliktu o Tajwan ,rosyjska flota Pacyfiku zatrzyma amerykańskie okręty płynące w jego stronę" 39 .

Pierwsze wspólne ćwiczenia bojowe - ośmiodniowa „Pokojowa Misja 2005” - odbyły się w południowo-wschodniej Rosji i chińskiej prowincji Shandong. Manewry odbyły się na lądzie, w morzu i powietrzu, a wzięło w nich udział 10 tys. jednostek. Szef rosyjskiego sztabu generalnego, oceniając takie wielostronne ćwiczenia, uznał je za pożyteczne i zadeklarował ich powtórzenie na płaszczyźnie wielostronnej, wspólnie z Indiami i Chinami lub w ramach Szanghajskiej Organizacji Współpracy ${ }^{40}$. Pod auspicjami tej organizacji odbyły się również ćwiczenia w 2007 r. (w Czelabińsku) i następnie w lipcu 2009 r., pod hasłem „Misja Pokojowa 2009”, w chińskiej prowincji Jilin. Ich tematem była walka z terroryzmem i separatyzmami etnicznymi. W oficjalnej wypowiedzi generał Makarow stwierdził, że obie armie, podejmując wspólne ćwiczenia, dążą do wyeliminowania wszelkich zagrożeń dla stabilności w regionie. Wzięło w nich udział 1300 oddzia-

38 D. Mierzejewski, op. cit., s. 184-185.

39 Russia's Primakov Urges ,, Strategic Triangle” with China, India, Agence France-Presse, 21.12.1998, s. 51-52.

40 „The Hindu”, 4.12.2005. 
łów, 22 rosyjskie samoloty, 40 chińskich samolotów wojskowych ${ }^{41}$. We wrześniu 2010 r. Chiny, Rosja, Kazachstan, Kirgistan i Tadżykistan, również pod auspicjami SOW, zorganizowały ćwiczenia „Misja Pokojowa 2010”, w uczestniczyło 5 tys. żołnierzy (personelu wojskowego).

Należy zwrócić uwagę na proporcje wspólnych ćwiczeń z Rosją. W latach 2002-2010 Chiny wzięły udział w 44 wspólnych ćwiczeniach bojowych, z tego w pięciu z Rosją. Chińscy generałowie są jednak zdania, że takie przedsięwzięcia budują zaufanie w kontaktach dwustronnych ${ }^{42}$. Rosyjski generał Nikołaj Makarow uważał, że naturalną konsekwencją ćwiczeń będą wspólne manewry sił morskich, ale szef sztabu generalnego chińskich sił zbrojnych Chen Bingde na razie tego nie przewiduje ${ }^{43}$.

W grudniu 2008 r. i w listopadzie 2009 r. odbyły się spotkania komisji dwustronnych na temat współpracy militarno-technologicznej. Jesienią 2010 r. minister obrony Anatolij Serdiukow i szef chińskiej centralnej komisji militarnej Guo Boxiong podpisali porozumienie o rozwoju współpracy wojskowej między dwiema stronami. Umowa dotyczyła przede wszystkim kontraktów na dostawy systemów obrony powietrznej i wyposażenia lotniczego ${ }^{44}$. W sierpniu 2011 r. rosyjski minister obrony rozmawiał o współpracy wojskowej z generałem Chen Bingde, który przebywał w Moskwie z delegacją wojskową.

\section{Sprzedaż rosyjskiej broni}

Handel bronią między obu państwami datuje się od 1992 r., ale negocjacje między stronami nie są łatwe. Największym problemem dla Rosji jest ochrona własności intelektualnej. W 1992 r. Chiny zakupiły 26 samolotów typu Su-27, a w listopadzie 1994 r. cztery rosyjskie łodzie podwodne.

W 1996 r. władze chińskie uzyskały licencję na wyprodukowanie 200 samolotów Su-27SK w ciągu kolejnych pięciu lat bez możliwości odsprzedaży ich państwom trzecim, a rosyjskie J-11A latają w korpusie lotniczym Shenyang. Kontrakt przewidywał dostawy rosyjskich lotniczych systemów elektronicznych, radarów oraz silników. Rosja unieważniła go, gdy w 2006 r. odkryła, że Chiny rozpoczynają produkcję J-11B z chińskimi systemami elektronicznymi oraz podsystemami. Decyzja pojawiła się, gdy Chiny wyprodukowały już co najmniej 95 maszyn $^{45}$. W listopadzie 1997 r. Chiny kupiły od Rosji dwa projekty niszczycieli typu 956E, a także seryjne wyposażenie do innych okrętów. W styczniu 2000 r. Rosja wyrazi-

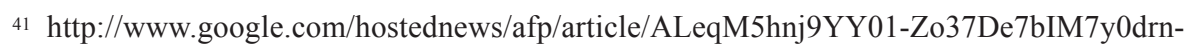
BPQ [dostęp 20.03.2010].

42 L. Jakobson, P. Holtom, D. Knox, J. Peng, China's Energy and Security Relations with Russia, SIPRI Policy Paper, 29.10.2011, s. 23.

43 Ibidem.

44 http://en.rian.ru/mlitary_news/20101109/161260856.html [dostęp 20.03.2011].

45 http://en.rian.ru/mlitary_news/20100604/159306694.html [dostęp 20.03.2011]. 
ła zgodę na produkcję najnowocześniejszych rosyjskich samolotów odrzutowych Su-30.

Od 2006 r. Chiny i Rosja negocjują sprzedaż Su-33 Flanker-D, które mogłyby być wykorzystane do produkcji chińskich lotniskowców, ale rozmowy ugrzęzły w martwym punkcie, ponieważ Chiny żądają przekazania dwóch próbnych samolotów. Rosyjski minister obrony utrzymuje, że odmowa jest związana z tym, iż Chiny wyprodukowały własną wersję Su-27SK, naruszając tym samym prawa własności intelektualnej ${ }^{46}$. Od 2001 r. Chińczycy produkują samoloty J-15, które Rosjanie uważają za kopie ich Su-33 Falcon-D. Prototyp Su-33 Chińczycy kupili od Ukrainy i użyli go do produkcji własnego samolotu. W 2009 r. Rosja ponownie odrzuciła propozycję sprzedaży Su-33, mimo że Pekin chciał kupić 14 egzemplarzy, twierdząc, że aby koszty produkcji się zwróciły, musiałyby sprzedać co najmniej 24 samoloty tego typu.

W 2010 r. Rosja dostarczyła Chinom 15 baterii S-300 systemów rakietowych ziemia-powietrze. Igor Aszurbeili, dyrektor generalny koncernu Almaz-Antei, stwierdził, że kontrakt winien być uzupełniony, ale nie wyjawił, o jaką wartość i o jaką liczbę S-300 chodzi ${ }^{47}$. Mimo to chińsko-rosyjska współpraca w dziedzinie technologii militarnej rozwija się. Na 15. spotkaniu chińsko-rosyjskiej międzyrządowej komisji wspólnej dotyczącej współpracy w tej dziedzinie w Pekinie strony przyjęły plan priorytetowych projektów.

Podsumowując ten aspekt współpracy chińsko-rosyjskiej, należy zwrócić uwagę na fakt, że na początku lat 90 . współpraca wojskowa była ważnym motorem rozwijania wzajemnych relacji. W latach 1991-2010 ok. 90\% chińskiej importowanej broni i sprzętu wojskowego było sprowadzane z Rosji ${ }^{48}$. Zadecydowało o tym sześć czynników: a) poziom technologii rosyjskiego przemysłu zbrojeniowego, b) konkurencyjność z innymi dostawcami, c) jakość eksportu rosyjskiej broni, d) rosyjskie relacje transferu broni do Indii, e) zainteresowanie kopiowaniem i f) współzawodnictwo Chin i Rosji na rynku broni ${ }^{49}$.

Jeśli chodzi o wielkość handlu, to w latach 1991-2010 stanowił on aż 90\% chińskiego importu uzbrojenia, z kolei dla Rosji broń stanowiła ok. 40\% eksportu do Chin $^{50}$. Szczyt wzajemnego handlu bronią przypada na rok 2005 i od tego czasu datuje się spadek.

Komisje wspólne na temat współpracy militarno-technicznej obradowały regularnie w latach 1992-2005, ale nie odbyły się spotkania w 2006 i 2007 r. Dla Chin współpraca w dziedzinie wojskowej z Rosją jest ważna ze względu na embargo UE i USA z 1989 r., a muszą dogonić sąsiadów, w tym Tajwan. Ponadto

\footnotetext{
46 Ibidem.

47 http://en.rian.ru/russia/20100402/158408294.html [dostęp 20.05.2011].

${ }_{48}$ L. Jakobson, P. Holtom, D. Knox, J. Peng, op. cit., s. 14.

49 Ibidem.

50 Ibidem.
} 
dzięki rosyjskim technologiom chińska armia może się modernizować. Z kolei dla Rosji po upadku ZSRR było to poważne źródło dochodów. Niemniej jednak problemem pozostaje ochrona własności intelektualnej, co Moskwa podnosi w kolejnych negocjacjach.

\section{Narzędzia gospodarcze}

Od lat 90. XX w. handel między obu państwami zaczął rosnąć. W roku 1991 jego wartość osiągnęła 3,8 mld USD, w 1992 - 5,8, a w 1993 - 7,7 mld USD. W 1994 r. Rosja wprowadziła jednak wysokie cła importowe i zaostrzyła przepisy wizowe dla Chińczyków. Obroty handlowe zaczęły wówczas spadać. Po spotkaniu premierów Zhu Rongji i Jewgienija Primakowa w Moskwie w lutym 1999 r. osiągnięto pewien postęp i podpisano kilka umów dotyczących budowy z udziałem kapitału chińskiego obiektów wydobywczo-przemysłowych gazu i ropy naftowej dla potrzeb chińskich ${ }^{51}$.

W 2007 r. wymiana handlowa osiągnęła wartość 48,16 mld USD, co oznacza wzrost o 44,3\% w stosunku do roku poprzedniego. W listopadzie 2006 r., w czasie wizyty premiera Rosji Michaiła Fradkowa w Chinach, doszło do podpisania 17 porozumień gospodarczych i zgodnie z rosyjskimi prognozami wartość chińskich inwestycji do 2020 r. powinna wynieść 12 mld USD. W listopadzie 2007 r., w czasie Rosyjsko-Chińskiego Tygodnia Promocji Inwestycji i III Chińsko-Rosyjskiej Konferencji Promocji Inwestycji, zorganizowanej w Pekinie, podpisano dziesięć projektów pomiędzy przedsiębiorstwami chińskimi i rosyjskimi, co oznacza, że Chińczycy zainwestują 1 mld USD w Rosji, ale również to, że rosyjskie przedsiębiorstwa inwestują w Chinach - w 2006 r. było to $600 \mathrm{mln} \mathrm{USD}^{52}$. W 2009 r. rosyjskie i chińskie kompanie podpisały porozumienia na budowę wspólnych projektów na terytorium Wschodniej Syberii i na Dalekim Wschodzie na kwotę sięgającą 8,7 mld USD ${ }^{53}$.

Od 2000 r. handel rosyjsko-chiński wzrósł znacznie: od ponad 6 mld USD do ponad 40 mld w 2008 r. W roku 2009 jego wartość jednak spadła z powodu deprecjacji rubla, co spowodowało, że koszty importu dóbr z Chin wzrosły. Ponadto spadły ceny ropy naftowej i produktów ropopochodnych, a wartość tych produktów stanowi ponad połowę rosyjskiego eksportu do $\mathrm{Chin}^{54}$.

51 D. Mierzejewski, op. cit., s. 186-187.

${ }_{52}$ Ł. Gacek, Chiny-Rosja: strategiczne partnerstwo czy nieunikniony konflikt? Wybrane aspekty ksztaltowania się relacji wzajemnych, [w:] Chińska polityka zagraniczna i jej uwarunkowania, pod red. J. Marszałek-Kawy, Wydawnictwo Adam Marszałek, Toruń 2008, s. 23-24.

$53 \mathrm{http}: / /$ constructive-project.org/en/analysis/5.htm [dostęp 15.11.2011].

54 Wartość handlu w 2000 r. - 8 mld USD, wzrost do 56,8 mld USD w 2008 r. Za: V. Portyakov, op. cit. 
Jeżeli porównamy dane statystyczne za rok 2010, to okaże się, że dla Rosji Chiny są bardzo ważnym partnerem handlowym; w gronie eksporterów znajdowały się na czwartym miejscu i eksport ten stanowił 5,4\% ogólnej wartości. Na pierwszym miejscu były Niemcy $-8,2 \%$, na drugim Holandia $-6 \%$, a na trzecim Stany Zjednoczone - 5,6\%. Natomiast jeśli chodzi o import, Chiny zajmują drugie miejsce, zaraz po Niemczech (14,7\%), i stanowi on $13,5 \%$.

W przypadku Chin w gronie ich najważniejszych partnerów, zarówno jeśli chodzi o import, jak i eksport, znajdują się państwa regionu: Hongkong, Japonia, Południowa Korea oraz Stany Zjednoczone, a z państw europejskich Niemcy. Rosja była 10. partnerem handlowym Chin ${ }^{55}$. W $2011 \mathrm{r}$. obroty handlowe wyniosły 83,5 mld USD, a w 2012 r. według szacunków - 90 mld USD. Najbliższy cel to 100 mld USD w ciągu 2-3 lat ${ }^{56}$.

Zastosowanie środków gospodarczych przez obie strony przybiera różne formy i ma bardzo duże znaczenie dla obu stron w kontekście realizacji ich polityki zagranicznej. Rosja, mimo że jest partnerem słabszym, demonstruje wolę konstruowania stosunków partnerskich i zgodnych z jej interesami, chroni własny rynek. W lipcu 2009 r. został zamknięty chiński rynek Czerkizowski w Moskwie, gdzie sprzedawano produkty według preferencyjnych taryf celnych; swój udział miało tu ok. 50 tys. chińskich kupców. Była to jedna z przyczyn reakcji chińskiej i zmniejszenia eksportu chińskiego do Rosji ${ }^{57}$. W roku 2010 handel między państwami ponownie ożywił się i osiągnął poziom sprzed kryzysu finansowego. Rosja stara się zmienić złą strukturę wzajemnego handlu. Eksportuje do Chin głównie surowce naturalne - ropa naftowa i produkty ropopochodne stanowią ok. 59\% eksportu do Chin, natomiast z ChRL Rosja sprowadza aż 54\% maszyn i urządzeń.

Dla Chin korzystny jest rozwój relacji z poszczególnymi podmiotami Federacji Rosyjskiej (FR). Obecnie ponad 70 podmiotów (miast i regionów) FR posiada sformalizowane kontakty z prowincjami w ChRL. Specjalne miejsce zajmuje rozwój współpracy regionów przygranicznych - budowa kompleksów handlowych, przejść przygranicznych, doskonalenie infrastruktury transportowej. Współpraca między północnymi Chinami a Rosyjskim Dalekim Wschodem i Wschodnią Syberią zaowocowała przyjęciem przez Rosję pierwszych 12 projektów priorytetowych ${ }^{58}$.

Popisany we wrześniu 2009 r. przez prezydentów Miedwiediewa i Hu Jintao dokument Rosja-Chiny 2009-2018. Pokazuje on, jakie priorytety mają Chiny, jeśli chodzi o współpracę z Rosją. Liczą głównie na dodatkowe źródła energii i surowców. Takimi inwestycjami są: Elektrownia Urgalska w regionie chabarowskim, Elektrownia Jerkowietska w regionie amurskim i linia przesyłowa z pod-

55 http://countryreport.mofcom.gov.cn/default.asp [dostęp 15.11.2012].

56 S. Luzanin, Rossijsko-kitajskij batans, http://www.mgimo.ru/news/experts/document233609. phtml.

57 V. Portyakov, op. cit.

58 http://www.fmprc.gov.cn/eng/wjb/zzjg/dozys/gjlb/3220/ [dostęp 5.11.2012]. 
stacji amurskiej do stacji na granicy z Chinami; linia typu AC łączy zazwyczaj oddzielne systemy energetyczne ${ }^{59}$. W załączniku do porozumienia wymieniono następujące kluczowe obszary współpracy: region Czity (Kraj Zabajkalski): berezowska kopalnia rud syderytu; Nojon-Tologojski kompleks wydobywczy: rudy cynku, ołowiu i srebra, kopalnie (kompleksy wydobywcze) w miejscowościach Nowoszirokinskoje, Bugdainskoje, Sołonieczenskoje, Kultuminskoje i inne ze złożami rudy żelaza, molibdenu, cynku, srebra, złota, ołowiu. Kolejnym regionem bogatym w surowce naturalne, którego dotyczy omawiana współpraca, jest region irkucki, następnie amurski, Żydowski region autonomiczny, chabarowski, sachaliński, z mgaczinskimi kopalniami węgla czarnego, oraz nowikowski z węglem brunatnym, a także region Magadanu i Kamczatki, czy wreszcie Czukotka, gdzie oprócz węgla znajdują się bogate, choć trudno dostępne złoża ropy naftowej ${ }^{60}$.

Spektakularny charakter ma współpraca w dziedzinie wydobycia ropy naftowej i gazu ziemnego. Na pierwszy rzut oka rozwija się bardzo dobrze i obie strony powinny być nią zainteresowane. Rosja jest zależna od eksportu surowców energetycznych (wedle raportu Bank of Finlandia z lutego 2008 r. ropa i gaz stanowią obecnie $50 \%$ rosyjskich całkowitych dochodów budżetowych oraz $65 \%$ wpływów z eksportu ${ }^{61}$ ), Chiny z kolei muszą zadbać o swoje bezpieczeństwo energetyczne. Własne zasoby ChRL nie są bowiem wystarczające, jeśli chodzi o bezpieczeństwo surowcowe i energetyczne. Tutaj pojawia się problem - chińsko-rosyjskim handlem ropy i gazu rządzi raczej polityka niż rynek ${ }^{62}$.

Chiny chronią swoje firmy, takie jak: SINOPEC (China Petroleum and Chemical Corporation), PetroChina i CNOOC (China National Overseas Oil Company), które mają się stać ważnym orężem polityki zagranicznej ${ }^{63}$. Zwłaszcza na początku lat 2000. polityka wewnętrzna i zagraniczna Pekinu była podporządkowana bezpieczeństwu energetycznemu, co wynikało z kilku przesłanek. Po pierwsze, inwazja USA na Irak spowodowała, że Chiny obawiały się o dostawy ropy. Kolejnym wyjaśnieniem polityki chińskiej z 2003 r. było przeświadczenie o uzależnieniu dostaw surowców energetycznych od Rosji. Prezydent Putin znacjonalizował Jukos i rurociąg, który miał być budowany z Angary (poludniowo-wschodnia Syberia) do Daqing (Chiny). Po trzecie, ceny na surowce energetyczne w Kazachstanie wzrosły. Chiny rozpoczęły więc współpracę z Australią, Arabią Saudyjską i Iranem. Rozpoczęto rozmowy dotyczące powołania konsorcjum, którego rolą miała być budowa zachodnio-wschodniej nitki gazowej, którą by transportowano gaz z Xinjiangu do Szanghaju. Rosyjski Gazprom początkowo

$59 \mathrm{http} / /$ constructive-project.org/en/analysis/5.htm.

${ }^{60}$ Ibidem.

${ }_{61}$ Ł. Gacek, op. cit., s. 28.

${ }^{62}$ Russo-Chinese Energy Relations. Politics in Command, Blue Ibex Ltd., Edinburgh 2006, s. 1.

${ }^{63}$ Ibidem, s. 2. 
miał uczestniczyć w projekcie, ale wyszedł z niego w 2004 r. Od tego czasu ukończono odcinek z Centralnej Azji do Chin. Nitka Atasu-Alashankou (KazachstanChiny) była częścią gazociągu z Aktubinska do Alashankou. W 2008 r. ruszyły dostawy ropy z Rosji do ChRL przez Kazachstan. Chiny zawarly z Kazachstanem umowę na budowę rurociągów dostarczających ropę i gaz z terenu Morza Kaspijskiego. W 2007 r. nitka rurociągu połączyła pola naftowe w Kazachstanie będące własnością China National Petroleum Corporation z chińską prowincją Xinjiang.

Przed 2011 r. ropę z Rosji transportowano głównie koleją. Chińczycy ponad dekadę proponowali budowę rurociągu, chcieli wyłączności, bo mogli wówczas mieć kartę przetargową w swoich rękach, zaś Japonia lobbowała, by rurociąg szedł aż do Pacyfiku, co oznaczało, że mógłby objąć inne państwa azjatyckie. Ostatecznie w czasie wizyty prezydenta Putina w Chinach (2006) uzgodniono wariant ESPO (East Siberia-Pacific Ocean) z odnogą do Daqing. Dopiero po 2009 r., kiedy Chiński Bank Rozwoju (China Development Bank) zgodził się udzielić kredytu (15 mld USD dla Rosnieft' i 10 mld USD dla Transnieft') zaczęto budowę. Rosja ma dostarczać $15 \mathrm{mln}$ ton ropy rocznie przez 20 lat. Zdaniem analityków, wreszcie pchnęło to do przodu rosyjsko-chińską współpracę energetyczną. Rurociąg otwarto w 2011 r. Ropę przerabia rafineria w Liaoyang niedaleko Daqing. Budowa nitki rurociągu do Kozmino nad Pacyfikiem rozpoczęła się w $2010 \mathrm{r}$.

Chiny mają obawy w związku z tą inwestycją, np., czy Rosja będzie w stanie sprzedawać tyle ropy. Nitka ropociągu została oddana do użytku w 2011 r., a już dwa miesiące po jej uruchomieniu koncern Rosnieft' oskarżył Chiny o jednostronne cięcie cen. Chińczycy zwracają uwagę na restrykcje w Rosji, jeśli chodzi o energetykę. Mowa jest też o tym, że Moskwa woli współpracować z Europą, a nie z Chinami. W sumie w 2010 r. import ropy naftowej z Rosji stanowił $6 \%$ chińskiego importu tego surowca, ale jest to import perspektywiczny. Obserwuje się jego wzrost. W 2000 r. rosyjska ropa stanowiła $2 \%$ importu chińskiego. Eksport ropy do Chin wzrósł z 1,8 mln ton w 2001 r. do 15,2 mln ton w 2010 r.

Jeśli chodzi o gaz, tutaj osiągnięcia są jeszcze mniejsze. Złoża gazu w Rosji są największe na świecie, a Chiny potrzebują więcej gazu, niż produkują. Dyskusje na temat poprowadzenia gazociągu z regionu Irkucka we wschodniej Syberii do Chin trwają od 1993 r. W dniu 3 listopada 2000 r. premier Rosji Michaił Kasjanow i premier Chin Zhu Rongji podpisali dokument dotyczący współpracy w dziedzinie badań techniczno-ekonomicznych, m.in. budowy gazociągu biegnącego ze złóż Kowykta w pobliżu Irkucka na Syberii do Chin. Planowano, że gazociąg będzie dostarczać w ciągu najbliższych 30 lat $20 \mathrm{mld}^{3}$ rosyjskiego gazu oraz przekazywać tranzytem 10 mld do Korei Południowej; miał przebiegać przez terytorium Korei Północnej. Złoża Kowykta to jedne z najbogatszych złóż gazu na świecie, to również jeden z ważniejszych projektów w ramach North-East Asian 
Regional Energy Corridor. Kowykta może gwarantować stabilne relacje współpracy między Chinami, Koreą i Rosją w przyszłości ${ }^{64}$.

W czasie 14. regularnego spotkania, w październiku 2009 r. w Pekinie, obie strony osiągnęły porozumienie o dostawach gazu do Chin, poczynając od 20142015 r. (do $\left.70 \mathrm{mld} \mathrm{m}^{3}\right)^{65}$. Zachodnia nitka będzie dostarczała przez sachaliński gazociąg $38 \mathrm{mld} \mathrm{m}^{3}$ zachodniosyberyjskiego gazu. Na początku $2011 \mathrm{r}$. CNPC i Gazprom uzgodniły budowę zachodniej linii do końca 2015 r., a wschodniej przed 2015 r. Strony nie zgodziły się jeszcze co do ceny. Rosja chce, aby były one zbliżone do cen w Europie, a Chiny - do ich cen wewnętrznych ${ }^{66}$.

Chiny szukają alternatywnych źródeł dostaw gazu, dlatego na marginesie rozważań o imporcie rosyjskiego gazu należy wspomnieć o kontrakcie z Turkmenistanem. W grudniu 2009 r. uruchomiono gazociąg z Turkmenistanu, przez Uzbekistan i Kazachstan, do Chin. Zgodnie z tym porozumieniem Chiny będą otrzymywać $30 \mathrm{mld}^{3}$ gazu rocznie przez 30 lat. Umowa ta ma wpływ na dwustronne relacje rosyjsko-chińskie i jest formą nacisku Chin, by zmiękczyć pozycję negocjacyjną Rosji, która do tej pory miała monopol na eksport gazu w Azji Centralnej i jedynie jedna nitka łączyła Turkmenistan z Iranem niezależnie od Rosji. Eksport gazu z tego rejonu był zależny całkowicie od infrastruktury rosyjskiej. Teoretycznie gazociąg Chiny-Azja Centralna burzy monopol Rosji na eksport gazu, ale w praktyce trudno o tym mówić. Interes Chin jest jeden - zaspokoić potrzeby własnego rynku. Istnienie wielu aktorów na rynku gazowym i zbalansowana struktura energetyczna w Azji Centralnej leżą jenak w interesie samych republik Azji Centralnej ${ }^{67}$. W grudniu 2009 r. wicepremier FR Igor Szuwałow podkreślał, że budowa gazociągów z Azji Centralnej do Chin nie wpłynie negatywnie na stosunki rosyjsko-chińskie i współpracę obu partnerów ${ }^{68}$. Obecnie procentowy udział eksportu chińskiego gazu ziemnego z Rosji stanowi ok. 4\%.

Opisując współpracę obu państw w dziedzinie surowców energetycznych, warto wspomnieć o przemyśle węglowym. We wrześniu 2010 r. Chiny i Rosja podpisały porozumienie o wartości 6 mld USD dotyczące budowy infrastruktury i oprzyrządowania kopalń węgla. Rosja zwiększy wydobycie węgla z $15 \mathrm{mln} t$ w 2015 r. do 20 mln t w 2035 r. ${ }^{69}$ Wspólne joint ventures ma być osiągnięte przy eksploatacji węgla w regionie Heilongjiang. Prowadzone są też inne rozmowy, np. na temat inwestycji chińskich w rosyjskiej kopalni Beringowski.

Kolejna ważna umowa dotyczy budowy elektrowni atomowej Tianwan w prowincji Jiangsu. W 1997 r. porozumienie podpisały China Jiangsu Nuclear Power Cooperation i Russia's Atomstroyexport. Pierwsze dwa reaktory (VVER-1000

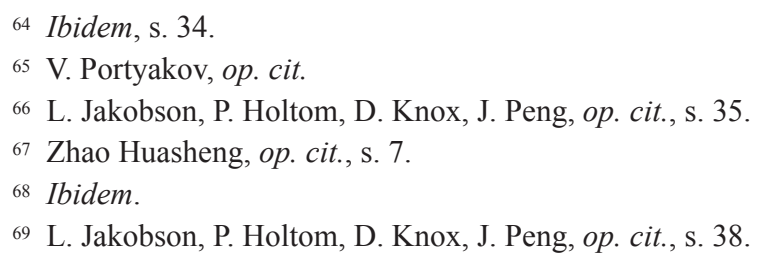


reactors) zostały oddane do użytku w 2007 r., a w marcu 2010 r., po negocjacjach cenowych i złożeniu alternatywnej oferty francuskiej, podpisano kolejne porozumienie o rozbudowie elektrowni oraz o współpracy dotyczącej reaktora prędkiego i wzbogacenia uranu. Strony uzgodniły, że Rosja ma za ten kontrakt otrzymać 1,3 mld euro ${ }^{70}$. Obecnie Chiny posiadają już własną technologię nuklearną i mogą stać się konkurencją na rynkach światowych dla rosyjskich koncernów ${ }^{71}$. Współpraca rozwija się też $\mathrm{w}$ innych sektorach energetyki, np. modernizacji sieci wysokiego napięcia - w 2011 r. podpisano kontrakty na sprzedaż energii elektrycznej.

Należy krótko wspomnieć również o budowie linii komunikacyjnych. W 2004 r. dziennik „China Daily” podkreślał, że należy zbudować nowy Jedwabny Szlak, łączący Chiny i Europę. Projekt taki istnieje, a w jego ramach jedna droga - o długości 13 tys. km - ma połączyć wschodnią Rosję z Rotterdamem, bazując na Kolei Transsyberyjskiej, druga - o długości 10900 km - ma biec z Lianyungang $\mathrm{w}$ prowincji Jiangsu do Rotterdamu, a trzecia - o długości 15 tys. km - z Shenzhen do Rotterdamu. W styczniu 2008 r. Chiny, Mongolia, Rosja, Białoruś, Polska i Niemcy podpisały porozumienie wprowadzające w życie realizację budowy pierwszego korytarza.

Wykorzystanie narzędzi gospodarczych w polityce zagranicznej Chin w odniesieniu do Rosji wydaje się najtrudniejsze. Projekty regionalne dotyczące przemysłu naftowego i gazowego są dla Chin najbardziej perspektywiczne i najważniejsze. Rosja z kolei opiera swój rozwój, jak do tej pory, na eksporcie tych surowców. Nie oznacza to jednak, że współpraca na tym polu rozwija się bezkonfliktowo. Moskwa włącza do gry instrumenty polityczne, aby zmienić strukturę handlu, zmniejszyć deficyt (co jej się udaje, ponieważ zmniejszył się on z 30 do $\left.13,1 \%{ }^{72}\right)$ i zwiększyć swój udział w obrotach handlowych Chin. Chiny są cały czas drugim partnerem, natomiast udział Rosji w obrotach handlowych ChRL pozostaje na 10-11. miejscu. Z punktu widzenia Pekinu taka sytuacja jest wygodna, ponieważ, jak zauważa ekspert ds. chińskich S. Luzanin, zmusza to Rosję do dokonywania bardziej „,azjatyckich”, a mniej proeuroepjskich wyborów, zamykając ją w regionie Azji Wschodniej ${ }^{73}$.

\section{Narzędzia kulturowe}

W stosunkach chińsko-rosyjskich wykorzystanie metod należących do szeroko pojmowanej sfery kulturowej (soft power) należy uznać za uzupełnienie pozostałych. Warto zaznaczyć, że sąsiedztwo obu państw, które trwa od 300 lat,

\footnotetext{
70 http://en.rian.ru/world/20100324/158301104.html [dostęp 18.11.2011].

${ }_{71}$ L. Jakobson, P. Holtom, D. Knox, J. Peng, op. cit., s. 40.

72 http://www.mgimo.ru/news/experts/document233609.phtm [dostęp 18.12.2012].

73 Ibidem.
} 
wymuszało wzajemne poznanie kultur i języków, jednak przez długi okres lat zimnowojennych, mimo że zainteresowanie sąsiadem istniało, nie było możliwości wykorzystywania szerokiego wachlarza metod soft power. Bazą dla dzisiejszej współpracy w tej dziedzinie jest porozumienie z 18 grudnia 1992 r. o współpracy kulturalnej, międzyrządowe Perspektywy współpracy kulturalnej oraz Program współdziałania między Ministerstwami Kultury Rosji i Chin na lata 2003-2005, podpisany w 2002 r. w Pekinie. Również w ramach SOW odbywają się rozmowy i wspólne narady ministrów kultury, np. w 2009 r. takie spotkanie odbyło się w Kazaniu.

Do tej pory przeprowadzono wiele znaczących imprez prezentujących i propagujących osiągnięcia kultury obu państw. Na przykład w latach 1997-1998 odbyły się wzajemnie dni kultury rosyjskiej w Chinach i chińskiej w Rosji. W 1999 r. w Chinach odbyły się uroczystości z okazji 200. rocznicy urodzin Aleksandra Puszkina i tydzień puszkinowski. Uroczyście obchodzono 50. rocznicę nawiązania stosunków dyplomatycznych i z tej okazji na Kremlu odbył się koncert Brawo Chiny, transmitowany w chińskiej telewizji. Z okazji 55. rocznicy zwycięstwa i zakończenia II wojny światowej Pekin gościł 14 znanych artystów rosyjskich z programem Pieśni z czasów wojny. Artyści brali udział w międzynarodowym festiwalu 2000 - spotkanie w Pekinie. Również w 2000 r. do Chin na tournèe pojechał zespół tańców ludowych Igora Mojsiejewa. Z kolei w Rosji gościli artyści z Chin: tancerze i zespół instrumentalny Pekińskiego Baletu i Opery - w sumie 55 osób występowało w Moskwie i Władimirze. Nie były to jedyne imprezy przewidziane na rok 2000, należy do nich doliczyć również wystawy i mniejsze przedsięwzięcia.

W grudniu 2000 r. chiński wicepremier Li Lanqing złożył oficjalną wizytę w Rosji, gdzie podpisał umowę dotyczącą konkretnych przedsięwzięć na lata 2001-2002, a także protokół współpracy między Ministerstwami Kultury obu państw obejmujący ten sam okres. Ponadto po raz pierwszy zwołano wspólną roboczą komisję zajmującą się sferami edukacji, kultury, zdrowia i sportu. W sierpniu 2001 r. w Pekinie odbyło się kolejne posiedzenie komisji, a dodatkowo zaczęły spotykać się podkomisje, które omawiały bardziej szczegółowe i węższe sfery możliwej współpracy; np. podjęto wspólne działania w sferze kinematografii.

Od kwietnia 2002 r. ministrowie kultury spotykają się w ramach Szanghajskiej Organizacji Współpracy. Postanowiono organizować festiwale kultury państw SOW.

W maju 2002 r. komisje kultury obu państw postanowiły zorganizować Dni Kultury Rosyjskiej w Chinach w 2003 r. i Dni Kultury Chińskiej w Rosji w 2004 r. W ich ramach w obu państwach zorganizowano liczne wystawy, występy, odczyty, a wymiana dotyczyła setek artystów z obu państw i wielu miast po obu stronach granicy. Dni kultury stały się centralnymi wydarzeniami współpracy kulturalnej w ramach SOW. Ich przebieg zakłóciły jednak epidemie grypy - przesunięto nieco terminy planowanych wydarzeń. Specjalne wydarzenia kulturalne 
towarzyszyły 60. rocznicy zwycięstwa i zakończenia Wielkiej Wojny Ojczyźnianej oraz 60. rocznicy zakończenia wojny z Japonią. Zaplanowano również inne ważne przedsięwzięcia kulturalne, tj. Rok Chin w Rosji i Rok Rosji w Chinach, na lata 2006-200774.

Kolejne inicjatywy tego typu podejmowane przez oba państwa to np.: Rok Języka Rosyjskiego w Chinach w 2009 r., który był największym wydarzeniem w relacjach dwustronnych. 13 października w Pekinie odbyła się uroczystość z okazji 60. rocznicy nawiązania stosunków dyplomatycznych i zamknięcia Roku Języka Rosyjskiego w Chinach. W ramach tego wydarzenia odbyło się wiele konkursów, odczytów, konferencji naukowych. Rok 2010 z kolei był ogłoszony Rokiem Języka Chińskiego w Rosji. W tym czasie również Rosja podjęła liczne działania pokazujące kulturę chińską i promujące naukę języka chińskiego ${ }^{75}$. Odbyło się aż 87 imprez edukacyjnych, kulturalnych, medialnych, publicystycznych, a w te przedsięwzięcia zostały włączone 23 federacyjne regiony Rosji. Obie strony otworzyły centra kultury, powstały podkomisje współpracy młodzieży, zajmujące się współpracą kulturalną i wymianą młodzieży. W 2010 r. pierwsza grupa 500 młodych Rosjan spędziła wakacje w Dalian i Qindao.

Jak już wspominano, Chińczycy, na wzór British Council, tworzą Instytuty Konfucjusza, których celem jest nie tylko nauka języka chińskiego, ale również propagowanie kultury i tradycyjnych wartości chińskich W Rosji działają 22 takie instytuty; najwięcej na Syberii i Rosyjskim Dalekim Wschodzie, w: Komsomolsku, Błagowieszczeńsku, Władywostoku, Irkucku, Eliście, Tomsku czy Nowosibirsku. Świadczy to o zainteresowaniu Pekinu propagowaniem języka chińskiego właśnie w tych regionach.

\section{Wnioski i podsumowanie}

Na współpracę chińsko-rosyjską duży wpływ ma czynnik amerykański. Państwa te współpracują przeciw unilateralizmowi USA. Idea świata wielobiegunowego i multilateralizm są powtarzane we wszystkich wspólnych oświadczeniach, deklaracjach i rozmowach Moskwy i Pekinu. Oba kraje sprzeciwiają się NATO jako organizacji interweniującej w sprawy wewnętrzne, razem nawołują do dialogu, a nie interwencji w sprawie Korei Północnej i Iranu. Razem potępiły one wycofanie się USA w 2001 r. z Traktatu ABM (Antibalistic Missile Treaty), podpisanego w 1972 r. Podobnie interpretują prawo każdego narodu do suwerennego decydowania o własnym systemie politycznym i odrzucają krytykę dotyczącą

${ }^{74}$ Szczegółowo na temat aktywności obu państw w dziedzinie kultury zob. http://www.chinafest.ru/site/svyazi_eng.php.

75 „Dychanije Kitaja” 2009, nr 4, s. 3-4. 
łamania praw człowieka. Rosja była w gronie 16 państw bojkotujących Pokojową Nagrodę Nobla dla Liu Xiaobo w 2010 r. Federacja Rosyjska i CHRL razem krytykowały Zachód za poparcie kolorowych rewolucji w Gruzji, Kirgistanie i na Ukrainie w latach 2003-2005. W 2011 r. wspólnie zajęły stanowisko w sprawie Egiptu, deklarując, że kraj ten powinien rozwiązywać swoje sprawy bez obcej interwencji, a w Radzie Bezpieczeństwa ONZ dwukrotnie odrzucały projekty rezolucji w sprawie Syrii. W 2008 r. zablokowały embargo dotyczące sprzedaży broni do Zimbabwe. Występując 4 lutego 2012 r. w Monachium na konferencji poświęconej problemom bezpieczeństwa, minister spraw zagranicznych Federacji Rosyjskiej S. Ławrow oznajmił, że Rosja nie będzie uczestniczyła w inicjatywach mających na celu powstrzymywanie Chin, które są jej dobrym sąsiadem i strategicznym partnerem ${ }^{76}$.

Oficjalnie Chiny i Rosja realizują wspólne interesy w Azji Centralnej za pośrednictwem SOW. Wspólne ćwiczenia wojskowe mają za zadanie m.in. chronić integralność terytorialną. Oba państwa pragną zachować suwerenne prawa do postępowania wobec mniejszości, stosując własne metody (Czeczenia, Ujgurzy i Tybet). Chinom z tego samego powodu nie w smak było oderwanie Północnej Osetii od Gruzji i włączenie jej do Rosji. Nie chcą ingerencji w sprawy wewnętrzne i separatyzmów, popierają jednak Rosję w sporze z Japonią o Kuryle. Rosja natomiast - w imię lojalności politycznej - popiera Japonię w sporze o wyspy Diaoyu/Senkaku, zachowuje neutralną postawę wobec sporu o archipelagi Spratly i Paracele i, podobnie jak Chiny, nie chce umiędzynarodowienia konfliktu.

W niektórych opracowaniach chińskich Rosja pojawia się jako najważniejszy partner $\mathrm{Chin}^{77}$. Wydaje się jednak, że są to zbyt daleko idące wnioski. Problem związany z budowaniem wzajemnych relacji, który najczęściej jest powtarzany w publikacjach naukowych i różnego typu analizach, to nadal brak zaufania. Chińczycy sądzą, że Rosja i Rosjanie myślą kategoriami europejskimi i nie chcą się konfliktować z Europą i Zachodem. Z kolei Rosjanie mówią o chińskim zagrożeniu na Syberii. Uważa się też, że silne Chiny mogą zmarginalizować Rosję. Na tej nucie grają Amerykanie, zachęcając Moskwę do odgrywania bardziej aktywnej roli w Azji Wschodniej.

Rosja obawia się ponadto wzrostu znaczenia Chin w Azji Centralnej - tradycyjnym obszarze wpływów rosyjskich. Wielu ekspertów widzi możliwą rywalizację chińsko-rosyjską w regionie, co jest widoczne w chińskich poszukiwaniach alternatywnych źródeł surowców energetycznych. Z kolei intelektualiści chińscy utrzymują, że nie chodzi o dominację, ale o zrównoważenie wpływów. Profesor Zhao Huasheng z Uniwersytetu Fudan twierdzi, że oba państwa z ich celami

76 W. Portiakow, O niekotorych osobiennostiach wnieszniej politiki Kitaja w 2009-2011, „Problemy Dalniego Wostoka” 2012, nr 2, s. 39.

77 S. Luzanin, Wnieszniaja politika Kitaja w głobalnych i riegionalnych izmierienijach, http:// www.mgimo.ru/news/experts/document216740.phtml [dostęp 18.12.2012]. 
regionalnymi nigdy nie będą wrogami czy adwersarzami, ale też nie będą przyjaciółmi ${ }^{78}$.

Jeśli chodzi o relacje gospodarcze, to Rosja dopiero nabiera dynamizmu rozwojowego, a gospodarka Chin jest już rozpędzona. Chiny stają się dla Rosji pierwszym partnerem, zaś Rosja dla Chin jest partnerem drugorzędnym. Ten brak balansu Moskwa stara się zmienić, jest partnerem trudnym i stawiającym warunki, jednak przewaga jest po stronie Chin.

Sprzedaż rosyjskiej broni spada, ale jednocześnie rozwija się współpraca w innych sferach, np. wspólne ćwiczenia. Peace Mission 2007 były największymi manewrami dla Chin w mijającej dekadzie, dzięki którym moły one demonstrować swoją rosnącą siłę militarną. Rosja jest jednym z kilku partnerów militarnych Chin, obok Indonezji, Pakistanu i Tajlandii.

Na pewno jednak współpraca polityczna będzie ważniejszą sferą wzajemnych relacji. Pozostaną punkty konfliktowe, ale strony będą szukać wspólnych interesów i stabilizacji. Chiny potrzebują przyjaznego zaplecza, bo nadal istnieje sporo nierozwiązanych konfliktów: spór o Senkaku z Japonią i o wyspy na Morzu Południowochińskim, wojna w Afganistanie, potencjalna niestabilność w Korei i Azji Centralnej, nieuregulowane kwestie graniczne z Indiami. Tymczasem problem granic z Rosją został zamknięty i można zaryzykować stwierdzenie, że mimo istniejących w tle wzajemnych relacji nieufności, Rosja pozostaje dla Chin partnerem strategicznym.

78 L. Jakobson, P. Holtom, D. Knox, J. Peng, op. cit., s. 12. 